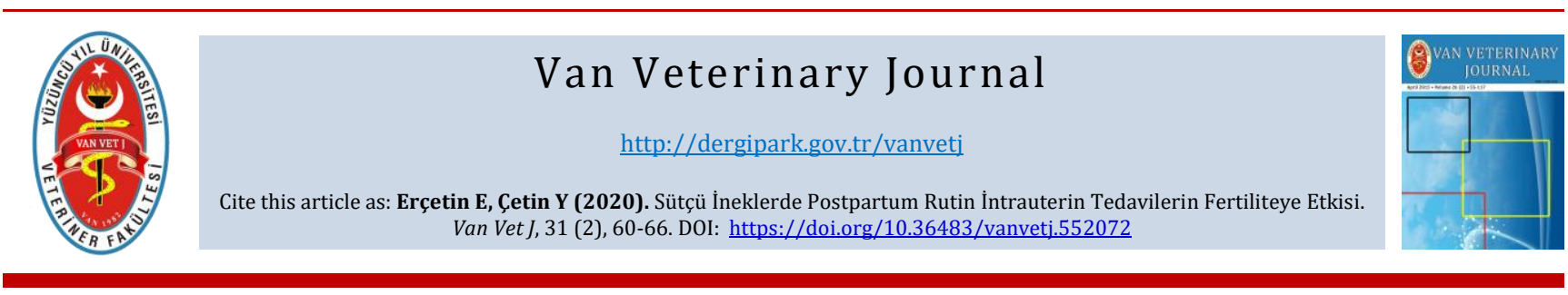

\title{
Effect of Postpartum Routine Intrauterine Treatment on Fertility in Dairy Cows
}

\author{
Egemen ERÇETINN ${ }^{*}$ (i) Yunus ÇETIN2 \\ 1 Veterinary Surgeon, Kirklareli, Turkey \\ ${ }^{2}$ Burdur Mehmet Akif Ersoy University, Faculty of Veterinary, Department of Obstetrics and Gynecology, Burdur, Turkey
}

Received: 22.04 .2019

Accepted: 19.02 .2020

\begin{abstract}
In this study, it was aimed to determine effect of postpartum routine intrauterin dimethyl sulfoxide (DMSO), DMSO + oxytetracycline and intramuscular $\mathrm{PGF}_{2} \alpha$ administration on fertility in cows. For this purpose, 150 cows were randomly divided into 3 groups for this study. Vaginal discharge and uterine size were scored with varying degrees from 1 to 3 . DMSO group $(n=47)$ first in the postpartum interval of 25 to 35 days, secondly in the postpartum interval of 40 to 55 days, were twice administered $120 \mathrm{ml}$ from $25 \%$ DMSO as intrauterine. In addition, $\mathrm{PGF}_{2} \alpha$ was administered at a luteolytic dose. For the DO group $(\mathrm{n}=46)$, first in the postpartum interval of 25 to 35 days in postpartum, secondly in the postpartum interval of 40 to 55 days, were twice $25 \%$ DMSO and $4 \mathrm{~g}$ oxytetracycline, all diluted with serum physiologic were administered $120 \mathrm{ml}$ as intrauterine. Furthermore, $\mathrm{PGF}_{2} \alpha$ was also given at the luteolytic dose. To the prostaglandin group $(\mathrm{n}=42) \mathrm{PGF}_{2} \alpha$ was given twice intramuscular luteolytic dose, firstly in 25-35 days and secondly in postpartum 40-55 days. Number of artificial insemination for one pregnancy, in cows with a vaginal discharge score of 1 , was accepted significantly lower than a vaginal discharge score of 2-3 $(\mathrm{p}<0.05)$. In antibiotic group, pregnancy rates did not differ according to $\mathrm{PGF}_{2} \alpha$ and DMSO usage. In early postpartum period, the use of intrauterine antibiotics was concluded that the effect on fertility parameters was not different from $\mathrm{PGF}_{2} \alpha$ and DMSO. It was concluded that intrauterine routine use of DMSO improves fertility proportionally but more cows should be studied.
\end{abstract}

Keywords: Dimethyl Sulfoxide, Fertility, Cow, Intrauterine, Routine

ÖZ

\section{Sütçü İneklerde Postpartum Rutin İntrauterin Tedavilerin Fertiliteye Etkisi}

Bu çalışmada, ineklerde postpartum rutin intrauterin Dimetil Sülfo Oksid (DMSO), DMSO + oksitetrasiklin ve intramuskular PGF2 $\alpha$ uygulamalarının fertiliteye etkisini belirlemek amaçlandı. Bu amaçla 150 baş inek rastgele 3 gruba ayrıldı. Vaginal akıntıları ve uterus boyutları 1'den 3'e değişen ölçüde skorlandı. DMSO gurubuna ( $\mathrm{n}=47)$ postpartum 25-35 gün aralığında ilki, postpartum 40-55 gün aralığında ikincisi olmak üzere iki defa serum fizyolojikle seyreltilen \%25'lik DMSO $120 \mathrm{ml}$ intrauterin olarak verildi. Ayrıca PGF2 $\alpha$ luteolitik dozda uygulandı. DO grubuna (n=46), postpartum 25-35 gün aralığında ilki, postpartum 40-55 gün aralığında ikincisi olmak üzere iki defa serum fizyolojik ile seyreltilen \%25'lik DMSO ve 4 gr oksitetrasiklin $120 \mathrm{ml}$ intrauterin olarak verildi, PGF2 $\alpha$ luteolitik dozda uygulandı. PG grubuna (n=42) 25-35 gün aralığında ilki, postpartum 40-55 gün aralığında ikincisi olmak üzere iki defa kas içi PGF2 $\alpha$ luteolitik dozda uygulandı. Vaginal akıntı skoru 1 olan ineklerde gebelik başı tohumlama sayısı akıntı skoru 2-3 olanlara göre anlamlı derecede düşük bulundu $(\mathrm{p}<0.05)$. Antibiyotik kullanılan grupta gebelik oranları PGF2 $\alpha$ ve DMSO kullanımına göre farklılık göstermedi. Erken postpartum dönemde intrauterin antibiyotik kullanımın fertilite parametrelerine etkisinin PGF2 $\alpha$ ve DMSO'dan farklı olmadığı sonucuna varıldı. DMSO'nun intrauterin rutin kullanımının oransal olarak fertiliteyi iyileștirdiği ancak daha fazla sayıda inekte çalışılması gerektiği sonucuna varildı.

Anahtar Kelimeler: Dimetil sulfo oksid, Fertilite, Inek, İtrauterin, Rutin

\section{GíRiș}

İneklerde doğum sonrası üreme performansı birçok farklı sebepten etkilenmektedir. İneğin laktasyon sayısı, postpartum dönemde vücut kondüsyon skoru (VKS) kaybı, doğum mevsimi, ketozis, hipokalsemi, uterus enfeksiyonları gibi nedenler üreme performansını etkilemektedir (Armengol ve Fraile 2015). Postpartum dönemde sıklıkla karşılașılan uterus enfeksiyonları, konsepsiyon oranını azaltmakta, doğum-ilk tohumlama aralığını uzatmaktadır. İneklerde sıklıkla karşılaşılan uterus enfeksiyonları, akut puerperal metritis, klinik endometritis ve subklinik endometritis şeklinde üç başlık olarak incelenmektedir. Akut puerperal metritis, 
pospartum 21 gün içerisinde, anormal büyümüș uterus, kırmızı-kahve renkte uterus akıntısı, $39.5^{\circ} \mathrm{C}$ ateș, sistemik enfeksiyon belirtileri, süt veriminde düşüş, durgunluk ve toksemi bulgularının seyrettiği uterus enfeksiyonu olarak tanımlanmaktadır. Postpartum 21. günden sonra vaginada purulent bir akıntının görüldüğü, sistemik bulguların eşlik etmediği uterus enfeksiyonlarına klinik endometritis denilmektedir. Klinik endometritiste servikal çap $7.5 \mathrm{~cm}$ ve üzeri olarak tespit edilmektedir. Süt ineklerinde klinik endometritis prevalansı 15-60. günler arasında \%23.6 ile \%42.6 arasında değişmektedir (Okawa ve ark. 2017). Postpartum dönemde klinik belirti göstermeyen ineklerde subklinik endometritisler görülebilmektedir. Klinik olarak endometritis görülmeyen ancak fertilite problemi olan ineklerden, sitobrush yöntemi ile uterus örneği alını polimorfonükleer (PMN) hücre sayısı araştırması yapılmış, düşük gebelik ile yüksek PMN arasında ilişki bulunduğu bildirilmiştir. $\mathrm{Bu}$ durumda subklinik endometritis tanımının uygun olacağı Kasimanickam ve ark. (2004) tarafından belirtilmiştir.

Endometritis nedeniyle oluşan ekonomik kayıpların en aza indirilmesi için en kısa sürede tedaviye başlanması gerekmektedir. Endometritis tedavisinde amaç yangısal değişikliklerin sonlandırılarak fertilitenin devamının sağlanmasıdır (Aslan ve ark. 1995; Sheldon ve ark. 2006; Azawi 2008). Tedavide antibiyotik, hormon, fitoteropetik ajan, antiseptik solüsyonu gibi maddeler intrauterin, parenteral ya da kombine olarak kullanılabilmektedir. Etkili bir endometritis tedavisi uterustaki inflamasyonu durdurmalı ve uterusun patojen bakteri yükünü immun sistemin baş edebileceği seviyelere düşürmelidir. Bunları yaparken uterusun savunma sistemini bozmamalı ve endometriyumda kalıcı hasarlar bırakmamalıdır (LeBlanc ve ark. 2002). Endometritis tedavisi parenteral tedavi, intrauterin tedavi veya her iki tedavinin beraber uygulanması gibi seçenekleri içermektedir. Parenteral endometritis tedavisi genellikle puerperal metritis olgularında tercih edilmektedir. Sıklıkla antimikrobiyal ajan ve hormonlar kullanılmaktadır. Klinik endometritislerde ise çeşitli antibiyotik ve antiseptik ajanlar intrauterin yolla yaygın olarak kullanılmaktadır. Fakat bunların çoğu intrauterin uygulama lisansına sahip değildir (Pascotini ve ark. 2016). İntrauterin yolla en çok tetrasiklinler kullanılmasına karşın etkinlikleri tartıșmalıdır (Armengol ve Fraile 2015). İntrauterin antibiyotik seçimi yaparken, antibiyotiğin endometriyuma irritan etkisi, anaerobik ortamdaki etkinliği, uterusun derin dokularına yayılabilme kapasitesi ve sütte kalıntı durumu dikkate alınmalıdır (Noakes ve ark. 2001). Özellikle dirençli uterus enfeksiyonlarında, etken maddelerin uterusun derin katmanlarına ulaşabilmesi için taşıt madde olarak Dimetil Sulfo Oksid (DMSO) kullanımının yararlı olabileceği bildirilmektedir (Küplülü ve ark. 2011). Dimetil Sulfo Oksid ilk olarak 1866 yılında Rus bilim insanı Alexander Zaytsev tarafından sentezlenen bir organosülfür bileșiğidir. Bu renksiz sıvı polar ve polar olmayan bileşikleri çözen, suyun yanında birçok farklı organik çözücü ile karışabilen polar aprotik çözücüdür (Wexler 2005). Birçok farklı tıbbi kullanım alanı bulunan DMSO'nun farmakolojik etkileri zar penetrasyonu, antienflamatuar özelliği, sinir blokajı etkisi ile lokal analjezik etkisi, bazı bakteri türlerinde bakteriostatik etkisi, diürezis etkisi olduğu, eș zamanlı uygulanan bir ilacın aktivitesini arttırabileceği, kollajen için çözücü olduğu, immunite ve vazodilatasyonda nonspesifik olarak artışa etkisi de dahil olmak üzere geniş bir primer farmakoloji alanı bulunduğu belirtilmiştir. Dimetil Sulfo Oksid, canlıların vücut zarlarını tahrip etmeden bir zarı kolayca geçebilmektedir. Bu geçiș esnasında bir dizi bașka bileșiklerinde geçișine izin vermektedir. Dokuları iskemi etkisine neden olabilecek durumlardan koruyabileceği belirtilen DMSO'nun, vazodilatasyonu ve trombosit agregasyonunu da inhibe ettiği belirtilmektedir. Kan dolaşımı kanallarını açık tutarak hücreler arası doku ödemini azalttığı bildirilmiştir (Ley ve ark. 1989). Doku yaralanması, dokularda iltihap ve eksüdasyon, hipoksik hasarlar, bağ doku nekrozuna neden olan bağ doku proliferasyonu, dolayısıyla belirli bir dereceye kadar skarlaşma meydana getiren vasküler yanitla sonuçlanmaktadır (Ley ve ark. 1989).

Sürü fertilitesinin optimum şartlarda devamı için postpartum 3. haftadan sonra devam eden endometritis olgularının tedavi edilmesi gerekmektedir. Anormal vaginal akıntı bulunmayan ineklerde de uterus enfeksiyonu bulunabilmektedir (Sheldon ve ark. 2006). Özellikle vaginitis ve metritis olgularının klinik muayene yöntemleri ile tam olarak ayrımının yapılamaması, subklinik endometritis teșhisi için sahada sitolojik yöntemlerin uygulama zorluğundan dolayı endometritis teşhisi koyulmadan doğum sonrası bütün ineklerin tedaviye alınmasının faydalı olabileceği düşünülmektedir. $\mathrm{Bu}$ amaçla çalışmada postpartum 25-35 ve 40-55. günlerde, endometritis olup olmamasına bakılmaksızın yapılan rutin intrauterin tedavilerin gelecek fertilite üzerine etkileri araștırıldı.

\section{MATERYAL ve METOT}

Çalışmada toplam iki farklı ișletmede bulunan 150 baş Holstein ırkı hayvan kullanıldı. Çalışma için Mehmet Akif Ersoy Üniversitesi, Veteriner Fakültesi, Etik Kurulu tarafından 271 numaralı etik kurul raporu onayı alınmıştır. Hayvanlar doğumdan sonra çiftlik şartlarında, ișletmenin rutin düzenine uygun olarak hazırlanan karma rasyon ile beslendi. Add libidum olarak ve sürekli ulaşabilecekleri yerlerde yeterli miktarda su bulunduruldu. İneklerde muayene ve tedavi sonrasinda yapılan suni tohumlama uygulamaları, tecrübeli bir teknisyen ya da veteriner hekim tarafından gerçekleştirildi. Araștırmada kullanılan ineklerin güç doğum durumları, yavru zarlarının atılma zamanı, metabolik, enfeksiyöz hastalık durumları kayıt altına alındı. Hayvanlara postpartum 25-35 günler arasında rektal muayene uygulanarak uterusun involüsyon durumu, akıntı varsa skorlaması yapıldı. Buna göre uterus invole olmuş ve pelvik çatı içinde ise (1. derece), uterus normalden büyük ve pelvik çatıdan biraz sarkmış ise $(2$. derece), uterus belirgin şekilde büyük ve karın boşluğuna doğru sarkık ise (3. derece) șeklinde puanlandı.

Vaginal akıntı puanlaması; akıntı yok veya saydam müköz ise (1. derece), yer yer purulent partiküller içeren müköz akıntıysa (2. derece), çok miktarda purulent akıntıysa (3. derece) șeklinde yapıldı. Bu muayeneler gerçekleşirken 5'lik sisteme göre vücut kondisyon skorları da kaydedildi. Postpartum 40-55 günlerde rektal muayene ve akıntı skorlaması aynı skala kullanılarak tekrarlandı. Genel durumu bozuk, klinik ve metabolik olarak sorunlu, şiddetli tırnak hastalığı olan, ketozis tedavisi gören, abomasum deplasmanı geçiren, ovaryum kisti bulunan ve çalışma sırasında mastitis tedavisi gören inekler araştırmadan çlkartıldı. İnekler uterustan gelen içeriğe ve involüsyon durumlarına bakılmaksızın, rastgele olarak her gruptaki hayvan sayısı eşit olacak șekilde 3 farklı gruba ayrıldı. Bu gruplar DMSO, DO ve PG olarak isimlendirildi.

Grup DMSO: Bu gruptaki ineklere ilk uygulama postpartum 25-35 gün aralığında, ikinci uygulama postpartum 40-55 gün aralığında olacak şekilde iki defa serum fizyolojikle 
seyreltilen \%25'lik DMSO (Dimethyl Sulfoxide Extra Pure Emplura; Merck Millpore Co., Germany)'dan $120 \mathrm{ml}$ intrauterin olarak verildi. Ayrica intrauterin tedavi günlerinde kas içi olarak PGF2 $\alpha$ (Gestavet Prost; Laboraorios Hipra Girona, Spain) luteolitik dozda uyguland.

Grup DO: Bu gruptaki ineklere ilk uygulama postpartum 25-35 gün aralığında, ikinci uygulama postpartum 40-55 gün aralığında olacak şekilde iki defa serum fizyolojik ile seyreltilen \%25'lik DMSO ve 4 gr oksitetrasiklin (Primavilin LA; Vilsan, Ankara, Türkiye) $120 \mathrm{ml}$ intrauterin olarak verildi. Ayrıca intrauterin tedavi günlerinde kas içi olarak PGF2 $\alpha$ luteolitik dozda uygulandı.

Grup $P G$ : Bu gruptaki ineklere ilk uygulama postpartum 25-35 gün aralığında, ikinci uygulama postpartum 40-55 gün aralığında olmak üzere iki defa kas içi PGF2 $\alpha$ luteolitik dozda uygulandı.

Tüm gruplarda postpartum 70 gününü dolduran inekler 10 gün doğal kızgınlık için izlendi. Uygulama sonrası postpartum 70. günden sonra tüm gruplarda 10 gün boyunca doğal kızgınlık takipleri yapıldı. Kızgınlık takipleri sabah ve akşam saatlerinde klinik gözlem ayrıca pedometre kayıtlarının izlenmesi yolu ile takip edildi. Doğal kızgınlık göstermeyen inekler ovsync yöntemi ile tekrar senkronize edilerek tohumland. Tohumlanan ineklerde 30 gün sonra transrektal USG yöntemi ile gebelik teşhisleri yapıldı. USG kontrolünde gebelik negatif sonuç veren inekler ișletmenin rutin reprodüksiyon yönetimine göre takip edildi. Uygulama gruplarında bulunan ineklerde yeniden klinik endometritis teșhisi yapıldığında ise $50 \mathrm{cc}$ (Primavilin LA; Vilsan, Ankara, Türkiye) intrauterin oksitetrasiklin tedavisi uygulandı ve kayıt altına alındı.

Postpartum yaklaşı 240 günü dolduran ineklerde grup başına gebelik oranı, açık gün ortalama sayısı, gebelik başına tohum sayısı, ilk tohumlama gebelik oranı gibi fertilite parametreleri incelendi. Çalışma boyunca toplamda 15 adet hayvan genel durum bozukluğu, klinik metabolik hastalık, şiddetli tırnak enfeksiyonu, mastitis vb. nedenlerden dolayı ikinci muayene-tedavi uygulamaları yapılmadan çalışmadan çıkarıldı.

Gebelik başına tohumlama sayısı = Tohumlanan hayvan sayısı / Gebe kalan hayvan sayısı,

Gebelik oranı = (Gruptaki gebe hayvan sayısı/ Gruptaki tüm hayvanların sayısı) X 100 şeklinde hesaplanmıştır.

Gruplarda açık gün ortalaması hesaplamasında ise hayvanların doğumundan gebe kaldığı aralığa kadar olan süre alınmıștır. Çalışma bittiği gün gebe kalmayan hayvanlar, sağılan gün sayısı alınarak ortalamaya dâhil edilmiștir.

\section{İstatistiksel analiz}

Mehmet Akif Ersoy Üniversitesi Veteriner Fakültesi Hayvan Sağlığı Ekonomisi ve İşletmeciliği Anabilim Dalı'nda SPSS programı kullanıldı, sonuçlar ortalama \pm standart sapma (SD) șeklinde verildi. $\mathrm{P}<0.05$ değerleri anlamlı kabul edildi. Tüm gruplara ait deneklerin uterus skorları ve akıntı skorları için tek yönlü varyans analizi kullanıldı. Akıntı skorlaması ve gebelik başına tohumlama sayıları, hayvanların gruplara göre gebelik oranları, ilk tohumlama sağmal gün ortalaması, ilk tohumlama gebelik oranı, açık gün sayısı, ortalama sağmal gün sayısı ve 3 tohumlama sonrasında gebelik bulguları gibi fertilite parametrelerini değerlendirmek için Pearson ki-kare testi uygulandı. Ayrıca, uterus boyutlarına göre açık gün ortalamalarında farklılıklar tek yönlü varyans analizi ve Tukey testi uygulanarak değerlendirildi.

\section{BULGULAR}

Tüm gruplar için 1 . ve 2 . muayene bulgularına göre ortalama uterus skorları, ortalama akıntı ve VKS skorları Tablo 1'de gösterilmiştir. Sadece DMSO grubunda dört inekte birer defa daha intrauterin oksitetrasiklin uygulamasıyla endometritis tedavisi yapılmıștır.

Gruplar arasında 1. ve 2. muayenede uterus skorları ve akıntı skorları arasında istatistiki olarak önemli bir fark görülmedi ( $\mathrm{P}>0.05)$.

Tablo 1. Muayenelerde belirlenen ortalama uterus skorları, ortalama akıntı ve VKS skorları $(\mathrm{P}>0.05)$

Table 1. Average uterine, vaginal discharge and body condition scores determined in examinations $(\mathrm{P}>0.05)$

\begin{tabular}{lccc}
\hline Gruplar & DMSO (n=47) & DO (n=46) & PG (=42) \\
\hline 1. Muayene Uterus Skorları & $1.5 \pm 0.6$ & $1.2 \pm 0.6$ & $1.5 \pm 0.5$ \\
2. Muayene Uterus Skorları & $1.2 \pm 0.5$ & $1.1 \pm 0.5$ & $1.3 \pm 0.4$ \\
1. Muayene Akıntı Skorları & $1.1 \pm 0.6$ & $1.1 \pm 0.6$ & $1.7 \pm 0.5$ \\
2. Muayene Akıntı Skorları & $1 \pm 0.4$ & $1.1 \pm 0.4$ & $1 \pm 0.1$ \\
1. Muayene VKS skorları & $2.9 \pm 0.3$ & $2.7 \pm 0.2$ & $2.9 \pm 0.3$ \\
2. Muayene VKS skorları & $3 \pm 0.3$ & $2.9 \pm 0.2$ & $2.9 \pm 0.2$ \\
Uygulama Sonrası Endometritis & 4 & - & - \\
\hline
\end{tabular}

Tablo 2. Grup ayrımı yapılmadan vaginal akıntı skorlaması ve fertilite parametreleri

Table 2. Vaginal discharge scoring and fertility parameters without group discrimination

\begin{tabular}{lccc}
\hline & Akıntı Skor 1 (n=113) & Akıntı Skor 2 ve 3 (n=22) & P Değeri \\
\hline Gebelik Oranı & $82.30 \%^{\mathrm{a}}$ & $63 \%^{\mathrm{b}}$ & $\mathrm{P}<0.05$ \\
Gebelik Başına Tohum Sayısı & $3.6 \pm 2.1^{\mathrm{a}}$ & $6 \pm 2^{\mathrm{b}}$ & $\mathrm{P}<0.05$ \\
Açık Gün Ortalaması & $152 \pm 75.8$ & $175 \pm 81.9$ & $\mathrm{P}>0.05$ \\
\hline
\end{tabular}


Tablo 3. Grup ayrımı yapılmadan uterus skorlaması ve fertilite parametreleri

Table 3. Uterine scores and fertility parameters without group discrimination

\begin{tabular}{|c|c|c|c|c|}
\hline Gruplar & $\begin{array}{c}\text { Uterus Skor } 1 \\
\quad(n=72)\end{array}$ & $\begin{array}{l}\text { Uterus Skor } 2 \\
\qquad(n=53)\end{array}$ & $\begin{array}{l}\text { Uterus Skor } 3 \\
\quad(n=10)\end{array}$ & P Değeri \\
\hline Gebelik Oranı & $72 \%$ ab & $86 \%{ }^{a}$ & $\% 50^{\mathrm{b}}$ & $\mathrm{P}<0.05$ \\
\hline Gebelik Başına Tohum Sayısı & $3.6 \pm 2.1^{\mathrm{a}}$ & $3.8 \pm 2.1^{b}$ & $7.2 \pm 2.5^{\mathrm{ab}}$ & $\mathrm{P}<0.05$ \\
\hline Açık Gün Ortalaması & $151.8 \pm 76.1$ & $156 \pm 77.2$ & $186.7 \pm 83.5$ & $\mathrm{P}>0.05$ \\
\hline
\end{tabular}

Tablo 4. Gruplarda bazı fertilite parametreleri $(p>0.05)$

Table 4. Some fertility parameters in groups ( $p>0.05)$

\begin{tabular}{lccc}
\hline Gruplar & DMSO (n=47) & DO (n=46) & PG (n=42) \\
\hline Grup gebelik oranı & $\% 87(41 / 47)$ & $\% 71.73(33 / 46)$ & $\% 78(33 / 42)$ \\
Doğum-ilk tohumlama aralı̆̆ı & $78.1 \pm 27.6$ & $90.1 \pm 29.9$ & $81 \pm 27.8$ \\
İlk tohumlama gebelik oranı & $\% 31.91(15 / 47)$ & $\% 34.78(16 / 46)$ & $\% 33(14 / 42)$ \\
Gebelik Başına Tohum Sayısı & 2.43 & 2.66 & 2.33 \\
Açık Gün Ortalaması & $149 \pm 75.9$ & $171 \pm 74.6$ & $147 \pm 80.1$ \\
Sağllan gün sayısı * & 241.2 & 240.1 & 243.3 \\
3 tohumlama sonrası gebelik oranı & $\% 74(35 / 47)$ & $\% 65(30 / 46)$ & $\% 62(26 / 42)$ \\
\hline
\end{tabular}

* Fertilite değerlendirmelerinin günü baz alınmıştır.

Grup ayrımı yapılmaksızın oluşturulan akıntı skorlaması ve fertilite parametreleri Tablo 2'de belirtilmiștir. Akıntı skorlaması ve gebelik başına tohumlama sayıları arasında ise istatistiki olarak önemli bir fark bulunmuştur $(\mathrm{P}<0.05)$. Gebelik oranı, akıntı skoru 1 olan hayvanlarda 2-3 olanlara göre daha yüksek bulundu ( $\mathrm{P}<0.05)$. Akıntı skorlamaları ile açık gün sayısı arasında istatistiki olarak fark bulunamamıştır. Açı gün sayısı ile akıntı skoru arasında fark bulunmasa da skor 2-3 olan hayvanlarda ortalama açık gün sayısı daha yüksek tespit edilmiştir. Ayrıca gruplar arasında akıntı ve uterus muayene skorlamaları arasında istatistiki açıdan bir fark bulunmasa da 2 . muayenelerde oransal olarak bir iyileşme olduğu saptanmıştır. Grup ayrımı yapılmaksızın oluşturulan uterus skorlaması ve fertilite parametreleri tabloda belirtilmiștir (Tablo 3). Uterus skoru 2 ve 3 olanlarda gruplar arasında gebelik oranlarında istatistiki bir fark bulunmuş $(\mathrm{p}<0.05)$, uterus skoru 1 ve 2 olan gruplar arasında ise istatistiki bir fark bulunamamıștır. Gebelik başına tohumlama sayısında da, uterus skoru 1 ve 2 olanlarda istatistiki fark bulunmuştur. Skor 1 ve 2 olanlarda oransal olarak skor 3 olanlara göre fark olmasına rağmen, istatistiki fark bulunamamıştır. Uterus boyutlarına göre değerlendirildiğinde ise, açık gün ortalamasında istatistiki fark bulunamamıștır. Tablo 4'de gruplara göre gebelik oranları, ilk tohumlama sağmal gün ortalaması, ilk tohumlama gebelik oranı, gebelik başına tohumlama sayısı, açık gün sayısı, ortalama sağmal gün sayısı ve 3 tohumlama sonrasında gebelik bulguları gibi fertilite parametreleri gösterilmiştir. Gruplar arasında istatistiki fark bulunmamıștır $(\mathrm{P}>0.05)$.

\section{TARTIŞMA ve SONUÇ}

Doğum sonrası bakteriyel kontaminasyon oluşan hayvanlarda postpartum ilk 3 haftalık süre içerisinde bakterilerin birçoğu elimine edilmektedir. $\mathrm{Bu}$ dönemde endometriyumun involüsyon süreci normal şekilde devam ediyorsa ilk 3 haftalı periyotta intrauterin tedavi girişimleri gereksiz bulunmaktadır (LeBlanc ve ark. 2011). Ancak daha sonra ki günlerde devam eden enfeksiyonlarda ise enfeksiyon kaynağının hayvanın immun sistemi tarafından elimine edilebilme oranı \%33 civarındadır (Sheldon ve ark. 2009). Postpartum vaginal akıntı skorlamasının bir sonra ki fertilite ile ilișkili olduğu bilinmektedir. Guliodori ve ark. (2017) postpartum 28. günden sonra yapılan vaginal akıntı skorlaması ve gebelik oranlarının birbiriyle ilişkili olduğunu belirtmişlerdir. Postpartum ilk 100 günde vaginal akıntı skoru 0 olanlarda gebelik oranının \%51.1 ( $\mathrm{n}=1615)$, vaginal akıntı skoru 1 olanlarda \%40.7 ( $\mathrm{n}=194)$, vaginal akıntı skoru 2 olanlarda \%24.2 (n=136) șeklinde azaldığını bildirilmiștir (Guliodori ve ark. 2017). Araştırmacılar vaginal akıntı skorunun artmasının ilk tohumlama gebelik oranlarını azalttığını ve gebe kalma için gereken süreyi uzattı̆̆ını belirtmektedirler. $\mathrm{Bu}$ araştırmada da vaginal akıntı skorlarıyla fertilite parametrelerinin ilişkili olduğu görülmektedir. Akıntı skoru 1 olarak tespit edilen hayvanların gebelik başına tohumlama sayıları daha düşük olarak belirlenirken, akıntı skoru 2-3 olan hayvanlara göre ise aradaki farkın istatistiki olarak anlaml olduğu görülmüştür $\quad(\mathrm{p}<0.05)$. Vaginal akıntıda purulent partiküllerin görülmesinin seksüel siklusun başlamasını geciktirdiği (Mateus ve ark. 2002), progesteron üretimini azalttığı (Williams ve ark. 2007), uterus ortamını bozduğu (BonDurant 1999) ve embriyonik gelişimi olumsuz etkilediği ve fertiliteyi düşürdüğü (Knutti ve ark. 2000) belirtilmektedir. Baez ve ark. (2015) uterus boyutlarıyla gebelik başına tohumlama sayısının ilişkili olduğunu, uterus hacmi büyük olan ineklerin tohumlama / gebelik oranın yüksek olduğunu belirtmişlerdir. $\mathrm{Bu}$ çalışmada uterus skorlaması 1 ve 2 olan hayvanlarda gebelik bașına tohumlama oranları arasında istatistiki olarak fark bulunmuștur $(\mathrm{p}<0.05)$. Uterus skoru 3 olan grupta, uterus skoru 1-2 olan gruba göre sayısal olarak gebelik bașına tohumlama oranı yüksektir. Ancak istatistiki olarak anlamlı bir fark bulunamamıștır. Bu durumun örneklem sayısının az olmasından kaynaklandığı düşünülmektedir. 
Araștırmacllar doğum öncesi vücut kondisyon skorunun postpartum endometritislerin kendiliğinden iyileșme oranını etkilediğini belirtmektedirler (Giuliodori ve ark. 2017). Doğum öncesi VKS 2.75- 3.25 arasında olan ineklerde kendiliğinden iyileşme oranı VKS 2.75' ten küçük veya 3.5 ten büyük olan ineklerdeki oranlardan daha yüksek bulunmuştur. Bu araştırmada doğum öncesi VKS bilinmediğinden böyle bir etkiyi gözlemlemek mümkün olmamıştır. Ancak postpartum VKS'nin 2.5 altına düşmemesi ve 2 . muayene zamanında VKS artışının görülmesi şiddetli bir negatif enerji dengesi yaşanmadığını göstermektedir. Postpartum așırı VKS kaybeden ineklerde metabolik profil ve immun baskılanmaya bağlı olarak endometritis olasılığının arttığı ve bununda düşük fertiliteye neden olduğu bildirilmektedir. Negatif enerji dengesinin sadece endometritis insidensini arttırmadığ aynı zamanda endometritisin iyileșme oranı üzerine de etkili olduğu bildirilmektedir (Giuliodori ve ark. 2017).

Okawa ve ark. (2017) postpartum uygulanan PGF2 $\alpha$ tedavisinin korpus luteum varlığına bakılmaksızın \%83.9 klinik iyileşme gösterdiğini bildirmişlerdir. Araştırmacılar PGF2 $\alpha$ uygulamasından sonra vaginal akıntı durumuna bakarak yaptıkları endometritis teşhisinde insidensin önemli derecede azaldığını bildirmektedirler (LeBlanc ve ark. 2002). Bununla birlikte 35 ve 49. günlerdeki çift doz PGF2 $\alpha$ tedavisinin sitolojik olarak teşhis edilen endometritislerde fertiliteyi iyileştirmediği bildirilmektedir (Dubuc ve ark. 2011). Giuliodori ve ark. (2017) da purulent vaginal akıntı görülen ineklerde PGF2 $\alpha$ uygulamasının fertiliteye olumlu bir etkisi olmadığını belirtmişlerdir. Postpartum PGF2 $\alpha$ uygulaması ile ilgili araştırmalarda çelişkili sonuçlar olduğu görülmektedir. Bazı vakalarda PGF2 $\alpha$ tedavisinin etkisiz kalmasının nedeninin endometritisin șiddeti ile ilgili olabileceği belirtilmektedir. Sunulan araștırmada ilk doz PGF2 $\alpha$ sonrasında vaginal akıntıda purulent partiküllerin azaldığı gözlenmiş fakat fark istatistiki olarak anlamsız bulunmuştur. Araştırmamızda tek başına PGF2 $\alpha$ uygulaması yapılan gruplar, fertilite açısından intrauterin tedavi yapılan DMSO ve DO gruplarına benzer sonuçlar vermiștir. İntrauterin antibiyotik uygulamalarında kullanılan antibiyotiğin türüne göre sütte antibiyotik kalıntısı oluşmaktadır (Gorden ve ark. 2016). Antibiyotiklerin bu risklerinden dolayı PGF2 $\alpha$ ile endometritis tedavisi önemli bir avantaj sağlamaktadır. İntrauterin uygulamaların iş gücü gerektirmesi ve inek açısından daha fazla stres oluşturması PGF2 $\alpha$ uygulamasının bir diğer önemli avantajlarından birisidir. Escherichia coli, Pseudomonas aeruginosa, Chlamydia penumonia gibi $\mathrm{Gr}(-)$ bakteriler kısraklarda kronik endometritisin ana nedenleri arasında gösterilmektedir (Kristen ve ark. 2017). Kronik endometritise neden olan bu Gr (-) bakteriler biyofilm oluşturmak suretiyle uterusun savunma mekanizmalarından ve antibiyotiklerin etkisinden kaçabilmektedir. Özellikle mastitis, metritis, endometritis, pneumoni ve yara enfeksiyonlarında biyofilm oluşturan bakteriler saptanmıştır. Kısraklarda DMSO, mukus, eksudat ve biyofilm gibi bariyerleri elemine etmesi özelliğinden dolayı klinik olgularda kullanılmaktadır. Kısrak endometriyumunda ülserasyona ve inflamatuar hücre oluşumuna yol açmamasından dolayı \%30'luk DMSO solüsyonu endometritis tedavisinde kullanılmaktadır. Kronik endometritis tedavisinde DMSO'nun etkilerinin kısmen kan dolaşımının artmasına neden olması, kısmen de dokularda anti-iskemik ve hipoksik koruyucu mekanizmalarla ilișkili olduğu bildirilmektedir (Ley ve ark. 1989). Kristen ve ark. (2017) \%30 luk DMSO'nun E. coli ve $C$. pneumonia tarafından olușturulan biyofilmleri parçaladığını ve canlı bakteri sayısını azalttığını göstermiștir. Ayrıca kısraklarda DMSO kullanımının anti-inflamatuar etkisinden dolayı endometriyal histolojik yapıyı iyileștirdiği, intrauterin tedavide yardımcı tedavi olarak kullanılabileceği, endometritis tedavisinde kullanımının gebelik oranlarını iyileştirebileceği belirtilmektedir (Ley ve ark. 1989).

İneklerde endometritis tedavisi amaciyla DMSO'nun kullanımıyla ilgili az sayıda araştırmaya rastlanmıștır. Bu nedenle DMSO'nun inek endometriyumundaki etkileri tam olarak bilinmemektedir. Ancak benzer bir etki mekanizmasıyla inek endometritislerinde de tedaviye katkı sağlama potansiyeli bulunmaktadır. Ahmadi ve ark. (2017) klinik endometritis belirtisi göstermeyen repeat breeder ineklerde endometriyumda biyofilm üreten bakteriler bulunduğunu bildirmișlerdir. Araştırmacılar \%10'luk DMSO solüsyonuyla uterus lavajı yapmanın biyofilm üreten bakteri sayısını yarı yarıya azalttı̆̆ını göstermişlerdir. $\mathrm{Bu}$ azalışın nedeninin DMSO'nun mukolitik özelliği ve bakteriyel biyofilm oluşumunu engellemesi olduğu düşünülmektedir. Uterus içi antibiyotik uygulamasından önce DMSO ile uterus lavajı yapmanın antibiyotik etkinliğini arttırdığı bildirilmektedirler (Ley ve ark. 1989). Bu çalışmada antibiyotiklerle beraber DMSO'nun kullanımı diğer gruplara göre istatistiki açıdan önemli bir fark oluşturmadı. Uterus içi antibiyotik uygulamasını DMSO ile beraber yapmak yerine, antibiyotik uygulaması öncesinde DMSO ile uterus lavajı yapmanın endometritis tedavisinde daha iyi sonuçlar vermesi beklenebilir. Bu çalışmada DMSO'nun tek başına kullanıldığı grup gebelik açısından oransal olarak daha yüksek bulunmuştur. Antibiyotiğin etkisini arttırmak amaciyla DMSO ve oksitetrasiklinin beraber kullanılması fertilite parametreleri açısından bir fark oluşturmadı. $\mathrm{Bu}$ durumun oksitetrasiklinin endometriyal iritasyona neden olmasindan kaynaklanabileceği düşünüldü. İneklerde endometritis tanısı koyulmadan doğrudan postpartum tedaviye alınmaları endometritis bulunmayan ineklerin de intrauterin tedavi görmesine neden olmaktadır. Bu yüzden sağlıklı bir endometriyuma sahip olan ineklerde oksitetrasiklin tedavisi sonrasında kimyasal bir endometritis oluşması muhtemeldir. $\mathrm{Bu}$ kimyasal endometritis riski DO grubundaki düşük gebelik oranlarının nedenini açıklayabilir.

İneklerde endometritis tedavisinde intrauterin oksitetrasiklin uygulaması yaygın olarak kullanılmaktadır. Uterus içi antibiyotik uygulamalarında amaç bakterilerin tamamını elimine etmek değil, bakteri sayısını uterus savunma mekanizmasının baş edebileceği miktara düşürmektir. İntrauterin oksitetrasiklin uygulaması, endometriyum üzerinde doğrudan irrite edici etkiye neden olabilmekte, inflamatuar yanitı uyarmakta, uterus savunma reaksiyonları ve uterus lumeninde polimorfonükleer (PMN) lökosit infiltrasyonunu teşvik edebilmektedir. Ayrıca uterus dokularının rejenerasyonunu da sağlayabilmektedir (Cohen ve ark 1995; Noakes ve ark. 2001). İntrauterin antibiyotik uygulamasında elde edilen tedavi etkisinin endometriyumdaki irritasyondan mı yoksa antibakteriyel etkiye bağlı olarak mı şekillendiği net olarak açıklık kazanmamıştır (Kaya 2008). İntrauterin oksitetrasiklin, paranteral PGF2 $\alpha$ ve östradiolün endometritis tedavisinde kullanıldığı bir çalışmada, tedavi edilen tüm hayvanlarda genel bașarı oranı \%68 olarak bulunmuş, oksitetrasiklin kullanılanlarda \%72, PGF2 $\alpha$ kullanılanlarda \%67, östrodiol kullanılanlarda ise \%62 olarak bulunduğu belirtilmiștir. Oksitetrasiklinin östradiolden daha etkili sonuç verdiği 
hafif endometritisli inekler hariç, tedavilerin başarı oranları arasında anlamlı bir fark olmadığı bildirilmiștir (Sheldon ve Noakes 1988). Önceki yıllarda yapılan çalışmalarda intrauterin oksitetrasiklin kullanımının fertilite açısından daha başarılı olduğu bildirilmektedir (Sheldon ve Noakes 1988; LeBlanc ve ark. 2002). Ancak inek endometritislerinden yaygin olarak izole edilen Truperalla pyogenes gibi bakterilerin son yıllarda oksitetrasikline karşı giderek direnç kazandığı görülmektedir (Malinowski ve ark 2011; Zhang ve ark 2017). Bu çalışmada da intrauterin antibiyotik uygulaması, kontrol grubuna göre fertilite açısından önemli bir fark oluşturmamıştır. Benzer şekilde Cetin ve ark. (2018) oksitetrasiklin içeren rutin intrauterin antibiyotik uygulamasının gebelik oranı üzerine etkisinin, hiçbir uygulamanın yapılmadığı kontrol grubundan farklı olmadığını bildirmiștir. Diğer taraftan oksitetrasiklin, intrauterin olarak uygulansa bile yüksek miktarlarda süte geçebildiği ve bunun metritisin derecesiyle de ilişkili olduğu bildirilmektedir (Gorden ve ark. 2016). Oksitetrasiklinin intrauterin uygulanmasindan sonra 1-8 gün arasında sütte kalıntıya neden olabileceği belirtilmektedir (Makki ve ark. 2016). Bu nedenle intrauterin oksitetrasiklin uygulanan inekler ayrı bir şekilde sağılacağı için çiftliklerde yönetimsel sorunlar meydana gelmektedir. Antibiyotiklerin, sütte kalıntı sorunu olușturmaları da göz önüne alındığında (Gorden ve ark. 2016) intrauterin kullanımları bile giderek daha çok sorgulanmaktadır.

Çalıșmada postpartum 15 gün arayla yapılan çift doz PGF2 $\alpha$ tedavisinin fertilite açısından intrauterin tedaviler kadar olumlu sonuç verdiği belirlenmiştir. Postpartum birinci ve ikinci muayenede belirlenen vaginal akıntı ve uterus skorlarının da uygulanan tedavilere bakılmaksızın gelecek fertilite açısından önemli bilgiler sağladığ görülmüștür. İntrauterin DMSO uygulaması sonrası gebelik oranlarının diğer gruplardan daha yüksek olduğu gözlenmiş, fakat bu fark istatistiki açıdan önemli bulunmamıștır $\quad(\mathrm{P}>0.05)$. İntrauterin antibiyotik uygulamasının yapıldığı grup ise fertilite parametreleri açısından oransal olarak daha düșük bulunmuștur.

1- Araștırmada DMSO'nun gebelik oranları üzerine etkisi istatistiki olarak ortaya koyulamadı. Ancak sayısal olarak olumlu bir fark mevcuttur. Sayıca arttırılmış bir popülasyonda DMSO uygulamasının fertiliteye olan etkisini daha net ortaya koyabileceği,

2- Postpartum vaginal akıntı skorlamasının gelecek fertilite açısından çok önemli bir parametre olabileceği,

3- Erken postpartum dönemde, rutin olarak intrauterin oksitetrasiklin uygulamasının fertilite parametrelerini olumlu etkilemediği,

4- İntrauterin oksitetrasiklin uygulamasının erken postpartum dönemde (25-35 gün), PGF2 $\alpha$ ya da DMSO ya göre fertilite parametrelerinde fark sağlamaması, antibiyotik kalıntı problemi ve uygulama zorluğu düşünüldüğünde kullanımının tekrardan gözden geçirilmesi gerektiği sonucuna varıldı.

\section{ÇIKAR ÇATIŞMASI}

Yazarlar, çıkar çatışması olmadığını beyan eder.

\section{KAYNAKLAR}

Ahmadi MR, Derakhshandeh A, Shirian S, Daneshbod Y, Ansari- Lari M Nazifi $S$ (2017). Detection of bacterial biofilm in uterine of repeat breeder dairy cows. Asian Pac J Reprod, 6 (3), 136-139.
Armengol R, Fraile L (2015). Comparison of two treatment strategies for cows with metritis in high-risklactating dairy cows. Theriogenology, 83 (8), 1344-51.

Aslan S, Arbaiter K, Dickie MB (1995). İneklerde puerperal dönemde düzenli kontrollerin fertilite üzerinde ki etkileri. Ankara Üniv Vet Fak Derg, 42, 307-315.

Azawi OI (2008). Postpartum uterine infection in cattle. An Reprod Sci, 105, 187-208.

Baez GM, Barletta RV, Guenther JN, Gaska JM, Wiltbank MC (2015). Effect of uterine size on fertility of lactating dairy cows. Theriogenology, 85 (8), 1357-66.

BonDurant RH (1999). Inflammation in the bovine female reproductive tract. J Anim Sci, 77,101-110.

Cohen Ro, Bernstein M, Ziv G (1995). Isolation and antimicrobial susceptibility of Actinomyces pyogenes recovered from the uterus of dairy cows with retained fetal membranes and post parturient endometritis. Theriogenology, 43, 1389-1397.

Cetin Y, Ö Güngör, İ Taşal, C Sipahi, S Sendag, A Wehrend (2018). Effects of postpartum intrauterine treatments on reproductive performance of dairy cows. Reprod Domest Anim, 53 (S1), 6.

Dubuc J, Duffield TF, Leslie KE, Walton JS, Leblanc SJ (2011) Randomized clinical trial of antibiotic and prostaglandin treatments for uterine health and reproductive performance in dairy cows. J Dairy Sci, 94 (3), 1325-38.

Giuliodori MJ, Magnasco M, Magnasco RP, Lacau-Mengido IM, Sota RL (2017). Purulent vaginal discharge in grazing dairy cows: Risk factors, reproductive performance, and prostaglandin F2 $\alpha$ treatment. J Dairy Sci, 100 (5), 3805-3815.

Gorden PJ, Ydstie JA, Kleinhenz MD, et al. (2016). A study to examine the relationship between metritis severity and depletion of oxytetracycline in plasma and milk after intrauterine infusion. J Dairy Sci, 99 (10), 8314-8322.

Kasimanickam R, Duffield TF, Foster RA, et al. (2004). Endometrial cytology and ultrasonography for the detection of subclinical endometritis in postpartum dairy cows. Theriogenology, 62, 9-23.

Kaya D (2008). İneklerde kronik endometritis olgularında lotogen $₫$, eucacomp ${ }^{\circledR}$ ve PGF2 $\alpha$ uygulamalarının fertilite parametreleri üzerindeki etkilerinin araștırılması. Doktora Tezi, Ankara Üniversitesi Sağlık Bilimleri Enstitüsü.

Knutti B, Busato A, Kü̈pfer U (2000). Reproductive efficiency of cows with endometritis after treatment with intrauterine infusions or prostaglandin injections or no treament. J Vet Med A Physiol Pathol Clin Med, 47 (10), 609-15.

Kristen DL, Ryan AF, Patrick MM, Grace IB, Margo LH, Bradley RB (2017). In vitro biofilm disruption and bacterial killing using nonantibiotic compounds against gram-negative equine uterine pathogens. J Equine Vet Sci, 53, 94-99.

Küplülü Ş, Vural R, Polat MI (2011). İneklerde uterus enfeksiyonlarının etiyopatogenezisi, klinik semptomları ve sağaltım girișimleri. Türkiye Klinikleri, 2(1), 58-65.

LeBlanc SI, Duffield TF, LEslie KE, et al. (2002). The effect of treatment of clinical endometritis on reproductive performance in dairy cows. $J$ Dairy Sci, 85 (9), 2237-49.

LeBlanc SJ, Osawa T, Dubuc J (2011). Reproductive tract defense and disease in postpartum dairy cow. Theriogenology, 76 (9), 1610-8.

Ley WB, Bowen JM, Sponenberg DP, Lessard PN (1989). Dimethyl sulfoxide intrauterine therapy in the mare: effects upon endometrial histological features and biopsy classification. Theriogenology, 32 (2), 263-76.

Makki M, Gheisari HR, Ahmadi MR (2016). Effect of different intrauterine oxytetracycline Treatment on reproductive performance of dairy cows with clinical endometritis and determination of oxytetracycline residues in milk. İstanbul Üniv Vet Fak Derg, 42 (1), 80-88.

Malinowski E, Lessa H, Markiewicz H, Kaptur M, Nadolny M, Niewitecki W (2011). Sensitivity to antibiotics of Arcanobacterium pyogenes and Escherichia coli from the uteri of cows with metritis/endometritis. Vet J, 187, 234-38.

Mateus L, da Costa, F, Bernardo F, Silva JR (2002). Influence of puerperal uterine infection on uterine involution and postpartum ovarian activity in dairy cows. Reprod Domest Anim, 37, 31-35.

Noakes DE, Parkinson TJ, England GCV (2001). Arthur's Veterinary Reproduction and Obstetrics. 8th Edition, WB Sounders London.

Okawa H, Fujikura A, Wijayagunawardane MMP, Taniguchi M, Takagi M (2017). Effect of diagnosis and treatment of clinical endometritis based on vaginal discharge score grading system in postpartum Holstein cows. J Vet Med Sci, 79 (9), 1545-1551.

Pascotini OB, Hostens M, Dini P, Vandepitte J, Ducatelle R, Opsomer G (2016). Comparison between cytology and histopathology to evaluate subclinical endometritis in dairy cows. Theriogenology, 86, 1550-1556. 
Sheldon IM, Brice SB, Cronin J, Gilbert RO, Gadsby JE (2009). Mechanisms of infertility associated with clinical and subclinical endometritis in high producing dairy cattle. Reprod Dom Anim, 44 (Suppl. 3), 1-9.

Sheldon IM, Lewis GS, LeBlanc S, Gilbert RO (2006). Defining postpartum uterine disease in cattle. Theriogenology, 65 (8), 1516-30.

Sheldon IM, Noakes DE (1988). Comparison of three treatments for bovine endometritis. Vet Rec, 142 (21), 575-9.

Wexler P (2005). Dimethyl Sulfoxide (DMSO) In: Encyclopedia of Toxicology 2nd Edition, Gad SE, Sullivan DW Ed(s), 166-168, Elsevier, USA.
Williams EJ, Fischer DP, Noakes DE, et al. (2007). The Relationship between uterine pathogen growth density and ovarian function in the postpartum dairy cow. Theriogenology, 68, 549-559.

Zhang D, Zhao J, Wang Q, et al. (2017). Trueperella pyogenes isolated from dairy cows with endometritis in Inner Mongolia, China: Tetracycline susceptibility and tetracycline-resistance gene distribution. Microb Pathog, 105, 51-56. 